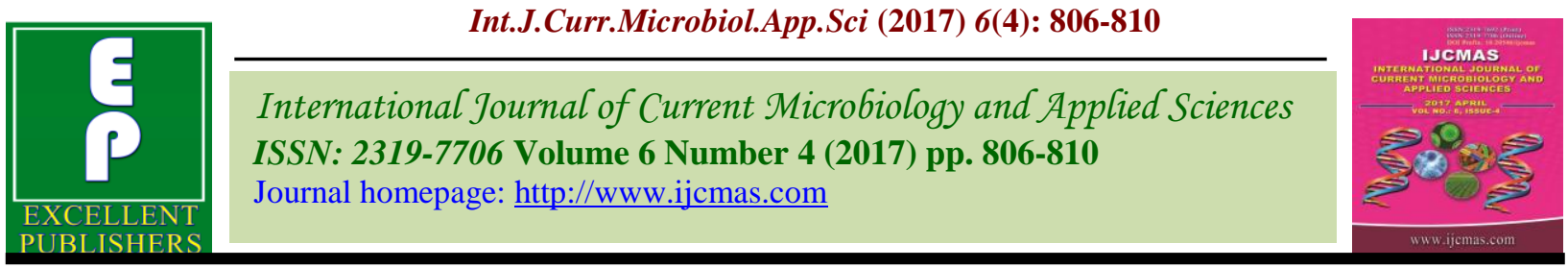

Original Research Article

https://doi.org/10.20546/ijcmas.2017.604.101

\title{
Incidence of Canine Parvo Virus-2 with Ancylostomosis and Complication by $E$. coli in a Young Pup
}

\author{
S. Saravanan* and K.M. Palanivel \\ Department of Veterinary Preventive Medicine, Veterinary College and Research Institute, \\ Tamil Nadu Veterinary Animal Sciences University, Namakkal-637 002, Tamil Nadu, India \\ *Corresponding author
}

\section{A B S T R A C T}

Keywords

CPV-2, Concurrent infection, PCR, Ancylostoma sp., E. coli.

Article Info

Accepted:

06 March 2017

Available Online:

10 April 2017
Canine parvovirus (CPV) is a highly contagious cause of serious and often fatal disease in dogs. An unvaccinated male non-descriptive pup of 4 months old with the history of pyrexia, frequent haemorrhagic diarrhea and vomiting was presented to the Infectious Unit of Teaching Veterinary Clinical Complex (TVCC), Veterinary College and Research Institute, Namakkal. The CPV infection was confirmed by polymerase chain reaction (PCR) with concurrent infection by Ancylostoma sp and complication by E.coli. However, the pup responded to the treatment positively with suitable antibiotics, anthelmintics and supportive therapy.

\section{Introduction}

Dogs are affected with various viral diseases viz., canine parvoviral infection, canine distemper, corona virus infection, canine hepatitis, canine parainfluenza and rabies (Bargujar, 2011). Canine parvovirus enteritis is a highly contagious and fatal disease of young dogs especially in the age group of 620weeks, transmitted by faeco-oral route (Nwoha, 2011). Parvo virus infection is most commonly manifested by vomiting, haemorrhagic diarrhea and severe leukopenia in dogs of all age, and myocarditis with subsequent heart failure in pups of less than 3 months of age (Nandhi et al., 2010). Pavo viral cases, if untreated, can rapidly progress to severe dehydration, complication by secondary invaders predominantly
Escherichia coli which lead to endotoxaemia, septicaemia and disseminated intravascular coagulation (DIC) resulting in a high case fatality (Monika Ling et al., 2012). However, CPV infections have been misdiagnosed, unfortunately due to the symptoms akin to some nematode infections viz., the hook worm infestation which could further negatively influence the recovery in the very young pups due to the prenatal transmission of the larvae (Goddard and Leisewitz, 2010). This paper presents the specific diagnosis of a case of parvo viral enteritis with co-infection by Ancylostoma and complication by E.coli, and its successful treatment in a nondescriptive dog. 


\section{Materials and Methods}

An unvaccinated male non-descriptive pup of 4 months old with the history of pyrexia, frequent haemorrhagic diarrhea, emesis, fever $\left(39.5 \mathrm{C}^{\circ}\right)$, dehydration and tachycardia was presented to the Infectious Unit of TVCC of VC \& RI, Namakkal (Fig. 1). Fecal sample was collected from the suspected dog by introducing a swab into the anus of diarrheic dog and homogenized (10\% w/v) in sterile phosphate buffer saline (PBS) in a $2 \mathrm{ml}$ collection tube. The sample was stored at $-20^{\circ} \mathrm{C}$ until further use for PCR.

\section{Extraction of DNA for PCR}

The fecal suspension with PBS was processed by centrifugation at $1500 \mathrm{xg}$ for $10 \mathrm{~min}$. Then supernatant $(500 \mu \mathrm{l})$ collected in a $2 \mathrm{ml}$ collection tube was boiled for $10 \mathrm{~min}$ at $100^{\circ} \mathrm{C}$ to inactivate the PCR inhibitors and chilled on ice. After boiling the sample was centrifuged at $1500 \mathrm{xg}$ for $5 \mathrm{~min}$ and the collected supernatant was used as a source of DNA template for the VP2 gene of CPV-2 (Behera et al., 2015). The lysate was stored at $-20^{\circ} \mathrm{C}$ until further use. The commercial vaccine against CPV, Canigen DHPPi (Virbac) was used as positive control and a stool sample collected from a healthy dog, processed similarly was used as a negative control.

A PCR master mix of $2 x$ (Ampliqon, Denmark) concentration in the reaction mixture and 100 bp DNA ladder (GeneDirex, USA) were used in the electrophoresis, with custom synthesized H-primers (Eurofins and Sigma, India) targeting the VP2 gene (Buonavoglia et al., 2001) with the product size 630bp were used in this study. The sequences of the primers were Forward: 5'CAGGTGATGAATTTGCTACA-3' and Reverse: 5'-CATTTGGATAAACTGGTG GT-3'. The extracted DNA was amplified using the selected primers by standardization of PCR with following reaction mixture and cycling conditions. A reaction mixture in 0.2 $\mathrm{ml}$ thin wall PCR tubes is prepared with the following composition: DNA template $-5 \mu$, master mix $-25 \mu$, forward and reverse primer (10 pico moles, each) - $1 \mu \mathrm{l}$ each and molecular grade water $-18 \mu \mathrm{l}$. The cycling conditions followed for the amplification are as follows: Initial denaturation- $-95^{\circ} \mathrm{C} / 5 \mathrm{~min}$, denaturation- $95^{\circ} \mathrm{C} / 60 \mathrm{sec}, \quad$ annealing$55^{\circ} \mathrm{C} / 2 \mathrm{~min}$ and extension $-72^{\circ} \mathrm{C} / 30 \mathrm{sec}$ with 30 cycles; and final extension $-72^{\circ} \mathrm{C} / 10 \mathrm{~min}$. The gel was visualized under UV transilluminator and the images were documented using the gel documentation system (Vilber Lourmat, France).

Fresh faecal sample was collected from the above case, subjected to centrifugal sedimentation and the sediment was examined microscopically for the presence of eggs which were identified based on morphological characters (Soulsby, 1982). Faecal swabs were collected aseptically for isolation of the enteric pathogens, E.coli and Salmonella. The faecal samples were streaked on eosine methylene blue agar (EMB), MacConkey agar and brilliant green agar, and incubated at $37^{\circ} \mathrm{C}$ for $24 \mathrm{hrs}$. Suggestive isolate of E. coli was identified by Gram's staining and biochemically, triple sugar iron (TSI) test as per the Bergey's Manual of Determinative Bacteriology (Holt et al., 1994).

\section{Results and Discussion}

The PCR revealed positivity for CPV-2 (Fig. 2) at $630 \mathrm{bp}$ and the faecal examination also revealed eggs of Ancylostoma sp (Fig. 3). Pink coloured colonies were identified on MacConkey agar and sub cultured on EMB which revealed characteristic bluish green colonies with metallic sheen indicative of $E$. coli. A change in colour from red to yellow and formation of acid butt and acid slant were noticed in TSI indicating E. coli. No colonial growth characteristic of Salmonella could be 
observed when streaked on brilliant green $\operatorname{agar}(\mathrm{BGA})$.

Treatment of CPV included intravenous IV fluids with electrolytes, antibiotics
(Amoxicillin@20mg.kg bwt), antiemetic (Ondansetran@0.2mg/kg bwt) and a broad spectrum dewormer comprising fenbendazole, pyrental pamoate and praziquantel to eliminate the helminthes.

Fig.1 A four months old male non-descriptive dog affected with CPV-2 showing haemorrhagic diarrhea

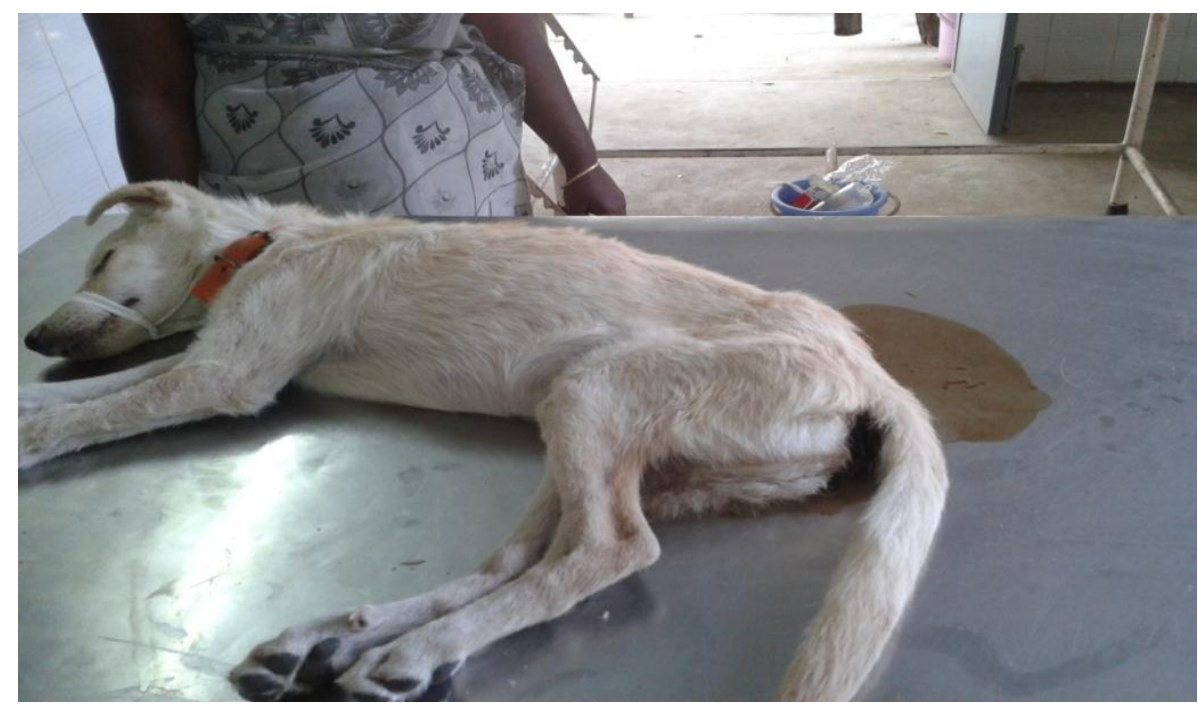

Fig.2 PCR showing band at 630bp using H-primer for CPV-2: Lane-1- Ladder (100bp), Lane-3: positive sample, Lane 5: positive control

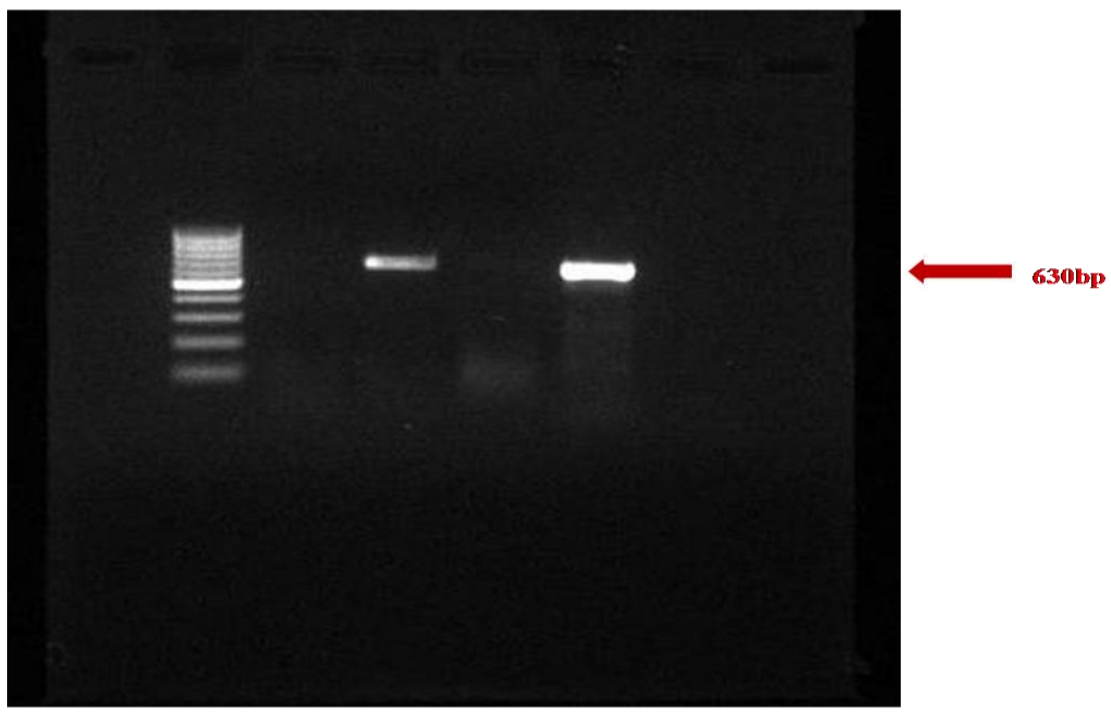


Fig.3 Egg of Ancylostoma sp in the faeces the parvo viral enteritis case

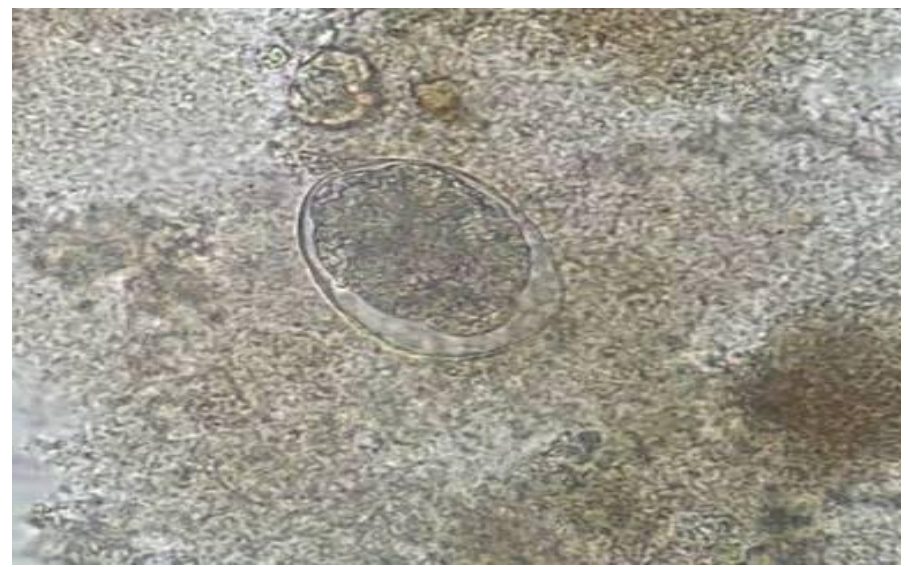

The case reported parvoviral enteritis in a dog of 4 months of age and this is in line with reports of Nwoha (2011), as the disease is associated with dogs within 6-20 weeks of age due to the window of susceptibility during which the low level of maternal antibody in the puppy is low. The clinical signs of parvo viral enteritis observed are in agreement with that of Uzuegbu (2015). Though electron microcopy, haemagglutination test, IFT and ELISA are employed in the detection of CPV, owing to their limitations in their detection, PCR is the technique found to be highly useful in the diagnosis of CPV-2 with high sensitivity and specificity (Manoj Kumar et al., 2010). The result of PCR is in accordance with Srinivas et al., (2013) who also reported an incidence of $53.90 \%$ for parvo viral enteritis by PCR assay using H-primers in Southern India.

The concomitant hook worm infestation could increase the severity of CPV enteritis due to the damage of the upper third of intestinal villi caused by the plug feeding of this parasite. This is in agreement with that of Uzuegbu (2015) who also recorded a coinfection with Ancylostoma in a mixed breed (Alsatian and Rottweiler).

Identification of colony characters on EMB agar is similar to that of Edwards and Ewing
(1972) and the biochemical reaction observed corroborated the finding of Sengupta et al., (2011). Nivi et al., (2010) also observed that dogs with CPV infection had an increased risk of secondary bacterial infections due to neutropenia and immunosuppression. The treatment followed is in agreement with that of Uzuegbu (2015) who also treated a similar case. Antibiotics were given to eliminate secondary bacterial infections and so avoid fatal septicaemia. The above treatment regimen used was very effective against the disease which was evident on day 5 of the treatment as the symptoms observed earlier had disappeared and the dog showed signs of recovery.

Hence, specific diagnosis of the parvo virus by confirmatory tests like PCR coupled with microscopic faecal examination could help in an unequivocal diagnosis and an early, specific treatment which is of paramount importance in the very young puppies of 6-8 weeks old that are at 'window of vulnerability' due to either predisposition by ancylostomosis to CPV-2 infection or coinfection by them.

\section{References}

Bargujar, J., A. Ahuja, D.K. Bihani, N. Kataria, and D. Dhuria, 2011. Studies 
on prevalence, clinical manifestations and therapeutic management in dogs suffering fromcanine parvovirus infection. J. Canine Dev. Res., 7: 9-16.

Behera, M., S.K. Panda, P.K. Sahoo, A.P. Acharya, R.C. Patra, S. Das and Pati, S. 2015. Epidemiological study of canine parvovirus infection in and around Bhubaneswar, Odisha, India. Vet. World, 8(1): 33-37.

Buonavoglia, C., V. Martella, A. Pratelli, M. Tempesta, A. Cavalli, D. Buonavoglia, G. Bozzo, G. Elia, N. Decaro and Carmichael, L. 2001. Evidence for evolution of canine parvovirus type 2 in Italy. J. Gen. Virol., 82(12): 3021-3025.

Edwards, P.R. and Ewing, W.H. 1972. Identification of Enterobacteriaceae. $3^{\text {rd }}$ edn. Burgess Pub. Co., USA.

Goddard, A. and Leisewitz, A.L. 2010. Canine parvovirus. Small Anim. Pract., 40: 1041-1053.

Holt, J.G., N.R. Krieg, P.H.A. Sneath, J.T. and StaleyWilliams, S.T. 1994. In: Bergey's Manual of Determinative Microbiology, Hensyl, W.R. (Ed.), $9^{\text {th }}$ Edn., Williams and Wilkins, Baltimore, USA.: 527-558.

Manoj Kumar, Sunil Chidri and Sukdeb Nandi. 2010. Molecular cloning and restriction endonuclease analysis of canine parvovirus DNA amplified by polymerase chain reaction. Global Veterinaria, 4(2): 125-129.

Monika Ling, Jacqueline, M., Norris, Mark Kelman and Michael, P., Ward. 2012. Risk factors for death from canine parvoviral-related disease in Australia Vet. Microbiol., 158: 280-290.

Nandhi, S., R. Anbuzhagan and Manoj Kumar. 2010. Strain differentiation and characterization of canine parvo virus by PCR and RE mapping. Indian J. Biotechnol., 9: 38-42.

Nivy, R., S. Hahn, S. Perl, A. Karnieli, O. Karnieli and Aroch. 2010. Fatal Outbreak of Parvovirus Infection: First Detection of Canine Parvovirus Type 2c in Israel with Secondary Escherichia coli Septicemia and Meningo encephalitis. Israel J. Vet. Med., 66(3): 96-102.

Nwoha, R.I.O. 2011. Parvoviral enteritis in a dog: case report and review of the literature. Continental J. Vet. Sci., 5(1): 6-10.

Sengupta, R., R. Das, S. Ganguly and Mukhopadhayay, S.K. 2011. Survey on microbial quality of chicken meat in Kolkata, India. Int. J. Res. in Pure and Appl. Microbiol., 1(3): 32-33.

Soulsby, E.J.L. 1982. Helminths, arthropods and protozoa of domesticated animals, $7^{\text {th }}$ edition Balliere Tindall, London.

Srinivas, V.M.V., H.K. Mukhopadhyay, P.X. Antony and Pillai, R.M. 2013. Molecular epidemiology of canine parvovirus in Southern India. Vet. World, 6(10): 744-749.

Uzuegbu, O.M. 2015. A case report on suspected parvoviral enteritis in a dog. Merit Res. J. Biochem. Bioinformatics, 3(2): 9-12.

\section{How to cite this article:}

Saravanan, S. and Palanivel, K.M. 2017. Incidence of Canine Parvo Virus-2 with Ancylostomosis and Complication by E. coli in a Young Pup. Int.J.Curr.Microbiol.App.Sci. 6(4): 806-810. doi: https://doi.org/10.20546/ijcmas.2017.604.101 